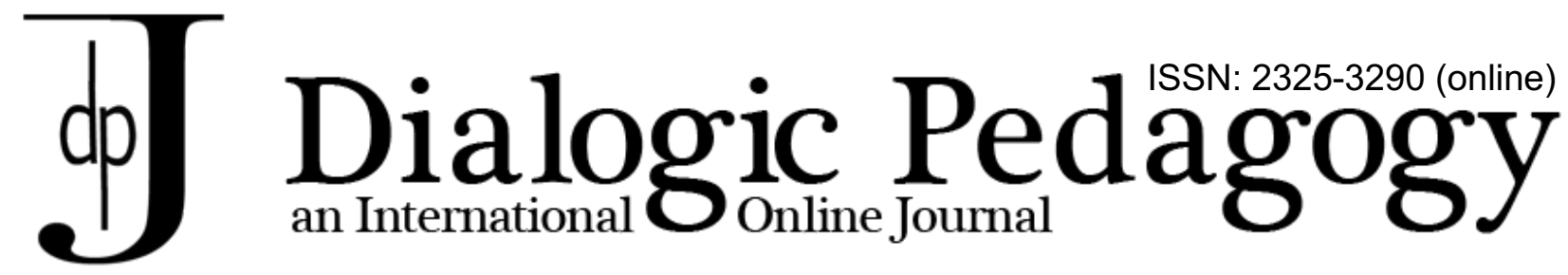

\title{
Free Will and Heutagogy
}
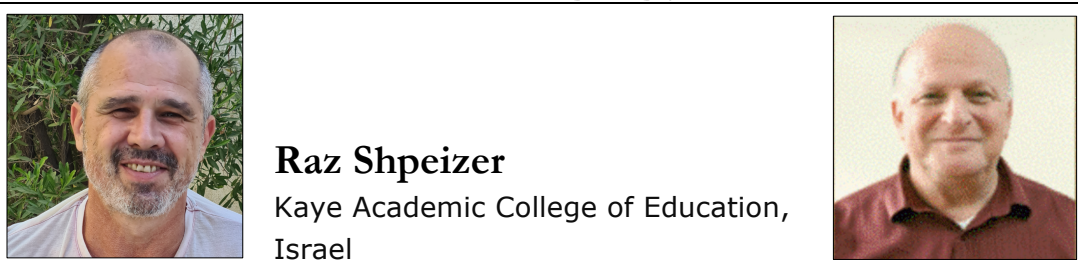

\author{
Amnon Glassner \\ Kaye Academic College of \\ Education, Israel
}

\begin{abstract}
In this paper we argue that there are at least two conditions for the adequate realization of the capacity of free will and thus of the realization of the right to freedom of education - that are missing from Matusov's account, and needed to be integrated with it in order to enable the successful implementation of the right to freedom of education principle. We will then offer a different typology of the field of education, a typology that is complementary, rather than contradictory, to Matusov's typology, and use this typology - especially the concept of heutagogy - to offer a way that optimizes freedom of will in education.
\end{abstract}

Dr. Raz Shpeizer is a lecturer and pedagogical instructor at Kaye Academic College of Education, BeerSheva, Israel. Born in Tel-Aviv, he graduated with bachelor's degree in Art and Philosophy and M.A degree in Philosophy from Tel-Aviv University. He then moved to Beer-Sheva in the south of Israel, to gain his PhD in Philosophy from Ben-Gurion University. He was appointed a lecturer at Kaye Academic College of Education in 2011, and since then teaches both undergraduate and postgraduate students as well as conducting researches. His fields of interest encompass general philosophy, philosophy of education, critical and creative thinking, project-based learning, and multiculturalism. He has published articles in various international and national journals, and a book about Henri Bergson and the problem of free will.

Amnon Glassner is a Senior Lecturer and Pedagogical Guide in Kaye Academic College of Education. His main research and teaching interests are: heutagogy approach; creative and critical thinking in education; argumentation skills; meaningful learning; intelligent use of ICT for meaningful learning. His papers were published in journals such as: Acta Psychologica, Learning and Instruction, British Journal of Educational Psychology, Journal of Thinking Skills and Creativity, and Journal of Action Learning. His last book was written with Prof. Shlomo Back: Exploring Heutagogy in Higher Education: Academia Meets the Zeitgeist

\section{Q2\$}

\section{Introduction}

One of the main aspects of the subject of freedom is that of free will. The free will theme is one of the core themes of Western philosophy and keeps haunting it for many centuries. However, the debates concerning free will tend to be very abstract, and mostly deal with its metaphysical and logical conditions (as well as their consequences to the concepts of moral responsibility). In this paper we will focus on the more practical aspect of free will, that is, its execution in real-life situations, and we will assume that free will do exist, since it seems to us that free will is both a logical condition of the freedom of education thesis and presupposed by Matusov (2020) when dealing with this thesis. 
Assuming that humans are endowed with the capacity of free will, and that this capacity is a necessary condition for the realization of the right to freedom of education, a question arises: Does the priority that Matusov gives to the principle of the right to freedom of education hinders in some way the full realization of this capacity? For if it does, it follows that this very right is being damaged.

In what follows, we will argue that there are at least two conditions for the adequate realization of the capacity of free will - and thus of the realization of the right to freedom of education - that are missing from Matusov's account, and needed to be integrated with it in order to enable the successful implementation of the right to freedom of education principle. We will then offer a different typology of the field of education, a typology that is complementary, rather than contradictory, to Matusov's typology, and use this typology - especially the concept of heutagogy - to offer a way that optimizes freedom of will in education.

\section{Two views of free will}

Beside views that deny the possibility of free will, and will not be dealt with here, there are two basic philosophical positions which suppose, and argue for its existence. These positions are compatibilism and libertarianism. The main difference between compatibilism and libertarianism is that the former holds that there is no contradiction between the concepts of determinism and free will, while the latter holds that for free will to be possible, indeterminism must be true. Thus, central to the libertarian views on free will is the principle of alternative possibilities (e.g., Ginet, 1996; Kane, 1996, 2005), which states that for every free action, there must be at least two possible actions that the agent can chose from, while compatibilists deny the necessity of this condition.

Of course, there is much more to be said about the compatibilism-libertarianism debate, but this cannot be done here due to space limitation. It is important to notice, however, that both views agree that some conditions, such as external coercion or manipulation, and agent's ignorance, would hamper free will (Berofsky, 2009; Kane, 2005; Pereboom, 2014), and also, that in order for an action to be considered free, the agent must be, in some sense, the author, or the source of this action.

In his paper, Matusov does not explicate his position regarding free will. Nevertheless, it seems to us that $\mathrm{h}=$ emphasizes the concept of choice (Matusov, 2020, pp. SF3, SF6, SF10, SF11, SF19, SF22), and he his free will view is close to the libertarian view. Therefore, in what follows, we will assume this view, but most of our arguments can be adopted (with slight modifications) as to encompass the compatibilist view as well.

\section{The argument from thinking skills}

Suppose that John studies in a university. Before the beginning of the semester, he reads a syllabus of a course entitled "critical examination," and, impressed by its rational, he decides to take the course. Heading toward the class for the course's first lesson, he meets another student - Emily. They discuss the course syllabus and Emily claims that while the syllabus is well-constructed, John should not believe everything written in it because obviously, the professor who wrote the syllabus has an interest in promoting it and attract students, and furthermore, she never heard any student saying something positive about this course, "So it must be a poor course." Convinced by her claims, John decides to give up the course and take another one instead.

Was John decision a free decision, and was he executing is right to freedom of education? Many would notice that John's change of mind was a result of erroneous reasoning, since Emily's argument is 
based on two logical fallacies - the circumstantial ad hominem and the argument from ignorance. However, some may feel reluctant to conclude that that fact alone is sufficient to establish that John's decision and the action that followed it were not free. After all, it seems that he could have decided otherwise, he was not forced to take this course of action, so cannot his decision be considered a free decision?

But what we would have thought if we knew that Emily's conversation with John was a premeditated attempt to manipulate him and cause him to leave the course (maybe she had a quarrel with the course's professor and looked for revenge)? Many philosophers have given examples of external manipulation, showing that people who are being manipulated to think, decide or act on the manipulator will cannot be considered free agents. These examples may be classified according to the strength of the manipulation from neuroscientists who can manipulate human's brain states (Pereboom, 2014) to social engineers who manipulate people behavior (Kane, 2005), to governments indoctrination, and so forth. The point is, that both common people intuitions, as exemplified in the law system (e.g., Murray \& Lombrozo, 2017), and philosophical considerations, lead to the conclusion that manipulated person is un-free, or at least less free - if the manipulation is understood as less forceful. The philosophical arguments for the impediment of free will in case of manipulation may vary according the philosophical orientation of the arguer. Thus, for compatibilists, the manipulee is less free because her manipulated act is less authentic, not expressing her deep self (Shoemaker, 2015), while for the libertarian, the loss of freedom is the outcome of the loss, or narrowing, of the range of possibilities, or, on other accounts, the loss of the ultimate authorship of the manipulee, who is no longer the source of her act (Kane, 1996, 2005). In our example, John initial decision to take the course was his own, and if we think of Emily's move as a premeditated manipulative move, we will probably be more inclined to accept that John's decision was not free because he could not be considered the author or source of it.

However, the most important point to be noticed is that John change of mind was due to an erroneous reasoning. This has nothing to do with any objective state of affairs in the outside world because neither John nor Emily, or, for that matter, anybody else, could knew (based on Emily's argument) whether taking the course was good for John or not. It was wrong judgment, which is the outcome of poor reasoning, and this poor reasoning, whether it was caused by intentional manipulation or not - brought John to take a course of action that otherwise he would have not taken, and thus damaged his ability to choose what is good for him.

Thus, it seems that basic thinking skill, or, more precisely, basic critical thinking skills, are needed for students, and persons generally, in order to make choices that are both more suitable for them, and, in a broader sense, freer. These skills might be less needed for villagers who live simple life in remote places, but in our modern societies, with the mass media, fake news, aggressive advertising, and strong and manipulative political and economic powers, it seems as a necessary condition for the actualization of free will. Moreover, even beyond the ever-present tangible possibility of manipulation, it should be noted that cases like the above case has nothing to do with the agent's right to act foolishly, irrationally, and so forth, since the action taken by John was a result of ignorance, and not of his (free) will to act as he wishes. At the bottom line, this means that without the ability for "reflective and reasonable thinking that is focused on deciding what to believe or do" (Ennis, 1985, p. 45), people will be less free, and students' right to freedom of education will be impaired.

Lastly, it is important to point out that the demand for basic critical thinking skills is far more modest and less pretentious than the Kantian ambitious portrayal of an all-embracing, truth-discoverer and moraldiscoverer reason. There is no need to assume, and indeed most critical thinking scholars will not assume, that reason discloses the absolute truth or the absolute moral principle(s). Rather, reason, or rationality, as 
the ability to weigh reasons (Paul, 1993; Siegel, 1988), helps us to avoid mistakes and wrong judgements, to better understand ourselves and the world, without necessarily supposing neither that it can reveal the ultimate truth nor that it is the only guide for action.

\section{The argument from lack of content}

Let us imagine, for example, a student who studies to become a teacher in a teacher education institution. She studies in a program which adopts the guidelines of the principle of the right to freedom of education, and thus, among other things, gets "to decide what to learn" (Matusov, 2020, p. SF10). After visiting few schools and learning their educational practices, she decides that she wishes to focus her entire learning on the prevailing practices she has seen in these schools, which - she rightly supposes - are the common practices of the entire educational system (she might reason that both her future student and herself would benefit from her becoming an expert in the established way of teaching).

Now, it seems to us that th: s student's freedom of choice, and thus her ability to act freely, is being damaged, rather than broadene ,ecause she is not aware of other educational options, such as, if we adopt Matusov (2020) terminology, the practices of close and open socialization and of education as critical examination. Yes, she might acquire knowledge of these other practices from "her interaction with the teacher, peers, other people, texts, experiences, observations, activities..." (Matusov, 2020, p. SF11), but she also might not, especially if she is inclined to stick with her initial decision. To put it more generally, in order to exercise free will, an agent needs possibilities, and the less possibilities there are, the less possibilities the agent is aware of, the lesser is her freedom, and vice versa - the more possibilities the agent has, the more possibilities the agent is aware of, the freer she is. In our present context, a student who is not aware of, and even more - does not have basic understanding of - the major trends in the l:-cipline or subject she wishes to study, cannot really execute her right to freedom of education, either jause she hardly has option to choose from, or because her choice is a mere guess.

\section{Pedagogy, andragogy and heutagogy (PAH)}

Following the above discussion about sw-zdom of will as a precondition for freedom of education, and referring to Matusov (2020) differentiatio stween "training, close socialization, open socialization, and critical examination, along with the Bakhtinian dialogic pedagogy" (p. SF3), we would like to present a complementary conceptual frame which expresses the different levels of learners' freedom of education, by identifying three major educational paradigms: pedagogy, andragogy and heutagogy (PAH).

Pedagogy assumes that the "learner is, by definition a dependent one" (Knowles, 1980, p. 43). The teacher takes full responsibility of determining what, when, and how something is to be learned, and to evaluate it. In pedagogy, the freedom of education is very limited. In pedagogy, "what is to be learnt, and how, is both determined and directed by the teacher; in andragogy [i.e., adult learning], it is determined by the teacher and directed by the learner" (Anderson, 2006, cited by Luckin et al., 2010). Pedagogy and andragogy differ from heutagogy (self-determined learning), in which "both determination and direction shift to the learner" (Luckin et al., 2010). Heutagogy enables the students to experience high level of freedom of education. Knowles (1970) defines self-determined learning as "...the process in which individuals take the initiative....in diagnosing their learning needs, formulating learning goals, identifying resources for learning, choosing and implementing learning strategies, and evaluating learning outcomes" (p. 7).

Using our and others' experiences in teaching heutagogy courses, we believe that we do not have to wait until the "intrinsic education occurs when our civilization transitions from the exclusively necessitybased to a leisure-dominated hybrid" (Matusov, p. SF23). Implementation of heutagogy enhances such 
education in schools and in higher education (see Blaschke, Kenyon \& Hase, 2014; Glassner \& Back, 2020). In the next section we expand on the characteristics of heutagogy, and its dialectical relations with the concept of free will and the issues of critical thinking skills and lack of content.

\section{Heutagogy: to implement freedom of education}

Heutagogy (Hase \& Kenyon, 2000) is a student-centered learning-teaching approach in which the learners, facilitated by a mentor/teacher, determine their own learning. They individually decide what, how, with whom, when, and in which environment to learn. They also choose how to evaluate their learning and its outcomes and how to present the knowledge they had created about the topic they have learned and about themselves as learners (Glassner \& Back, 2020).

According to the connectivism theory (Simense, 2008), heutagogy presupposes that knowledge (tying connections) in its nature is usually organized as a mesh network (each node is connected to the others nodes), in addition to other traditional networks such as a ring (circle), tree (roots and brunches algorithm) and bus-line (linear) (Glassner \& Back, 2020).

Following this presupposition, we suggest that heutagogy learning is characterized by learners' wandering in mesh network and by handling symmetric dialogue (without authority) with their teachers. The learning is for its own sake, although it might have instrumental ends (Glassner \& Back, 2020). In addition, the ethical aspect of learning should promote freedom, democracy, and tolerance toward others.

Referring to Matusov (2020, p. SF10-SF11) elements of freedom of education, heutagogy enables the student's freedom to choose the curriculum, instruction, participation, valuation, ecology and leisure. n-e can argue, though, that in heutagogy students are limited in their freedom to choose their role and adigm, as they are expected to be self-determined learners.

We cannot and should not force students to participate in heutagogy learning, but we can invite $\mathrm{m}$ to experience it by facilitating their self-determined learning. The lecturer/teacher has to fully trust her students' capability to be self-determined learners (Glassner \&Back, 2020). In addition, when students choose to learn in groups it might help some of them to feel more comfortable and secure. However, working in groups can discourage the individual from being self-determined.

In order to cope with the obstacles of freedom of will mentioned above (lack of content that limits more freely choosing and lack of critical thinking skills), we take some practical steps in our version of heutagogy courses.

Fostering curiosity to learn and expanding choices for learning: This is a preliminary stage to the self-determined learning, in which, we, the lecturers, expose the central ideas, issues and questions of the course's general subject. Such exposure enables the students to develop their own ideas about what they wish to learn in the course. Although this preliminary stage represents more pedagogy than heutagogy, it enables the students to increase their freedom of will and education by expanding their choices to identify what they wish to learn in the course (Glassner \& Back, 2020).

Enhancing a dialogical critical thinking environment: In our heutagogy courses, the students are ited to initiate genuine dialogues with us and among themselves, using different communication ways $d$ tools they choose (e.g., face to face meetings or remoted correspondence like e-mails). In these dialogues they are invited to discuss their learning aims, desires, believes, blokes, challenges and difficulties. The students are encouraged to reflect upon their decisions, attitudes and preferences, and try 
to understand their origins and how they can justify them. In this way they develop their critical thinking, unpack their deep personality, and discover their authentic identity (Glassner \& Back, 2020).

\section{Conclusion}

There is no absolute freedom, rather, there are different levels of freedom, and in order to get closer to the higher levels of freedom, certain conditions are needed. This means that freedom is a dialectical concept, because necessity is interwoven within it. Content knowledge and basic critical thinking skills are two of the conditions needed for elevating free will, and thus the execution of the right to freedom of education, to those higher levels. Surely, there are more conditions (e.g., some reflective capacity), and further mapping and understanding them can contribute to the important subject of freedom of education. Here, however, we have focused on these two, trying to show both their importance, and the way heutagogy tries to integrate them with the aspiration for freedom of education, in a way that harms this freedom as less as possible. Thus, heutagogy presents an educational paradigm which acknowledges the tension that is built-in within the concept of freedom, a tension we should strive to soften as much as possible, without hoping for its complete resolution, since this tension is part and parcel of freedom itself.

\section{References}

Berofsky, B. (2009). Liberation from self: A theory of personal autonomy. New York: Cambridge University Press.

Blaschke, L. M, Kenyon., C. \& Hase. S. (Eds.) (2014), Experiences in self-determined learning (pp. 8496). Kindle Edition: CreateSpace Independent Publishing Platform.

Ennis, R. H. (1985). A logical basis for measuring critical thinking skills. Educational

Leadership 43(2): 44-48.

Ginet, C. (1996). In defense of the principle of alternative possibilities: Why I don't find Frankfurt's arguments convincing. Philosophical Perspectives, 10, 403-417.

Glassner, A. \& Back, S. (2020). Exploring heutagogy in higher education - academia meets the zeitgeist. Springer Nature, Singapore.

Hase, S., \& Kenyon, C. (2000). From andragogy to heutagogy. Ultibase Articles, 5(3), 1-10.

Kane, R. (1996). The significance of free will. Oxford: Oxford University Press.

Kane, R. (2005). A contemporary introduction to free will. Oxford: Oxford University Press.

Knowles, S. M. (1970). The modern practice of adult education. New York: Association Press.

Knowles, S. M. (1980). The modern practice of adult education (revised and updated ed.). Chicago: Follett Publishing Company.

Matusov, E. (2020). A student's right to freedom of education. Dialogic Pedagogy: An International Online Journal, 8 (2020), SF1-SF28. doi:10.5195/dpj.2020.356.

Murray, D. \& Lombrozo, T. (2017). Effects of manipulation on attributions of causation, free will, and moral responsibility. Cognitive Science, 41, 447-481, doi: 10.1111/cogs.12338

Luckin, R., Clark, W., Garnett, F., Whitworth, A., Akass, J., \& Cook, J. (2010). Learner-generated contexts: A framework to support the effective use of technology for learning. In M. Lee \& C. McLoughlin (Eds.), Web 2.0-based e-learning: Applying social informatics for tertiary teaching (pp. 70-84). Hershey: IGI Global. 
Paul, R. W. (1993). Critical thinking: What every person needs to survive in a rapidly changing world. Santa Rosa, CA: Foundation for Critical Thinking.

Pereboom, D. (2014). Free will, agency, and meaning in life. Oxford: Oxford University Press.

Shoemaker, D. (2015). Ecumenical attributability. In R. Clarke, M. McKenna \& A. Smith (Eds.), The nature of moral responsibility (pp. 115-140). Oxford: Oxford University Press, Retrieved from: Retrieved from: https://www.academia.edu/9320076/Ecumenical Attributability"

Siegel, H. (1988). Educating reason: Rationality, critical thinking, and education. New York: Routledge.

Siemens, G. (2008). Learning and knowing in networks: Changing roles for educators and designers. Presented to ITFORUM for Discussion. Retrieved from: http://www.itdl.org/journal/jan 05/article01.htm.

\section{(cc) EY}

New articles in this journal are licensed under a Creative Commons Attribution 4.0 United States License.

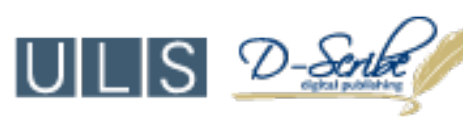

This journal is published by the University Library System, University of Pittsburgh as part of its D-Scribe Digital Publishing Program and is cosponsored by the University of Pittsburgh Press. 